\title{
Regulation of DNA gyrase operon in Mycobacterium smegmatis: a distinct mechanism of relaxation stimulated transcription
}

\author{
Shyam Unniraman and Valakunja Nagaraja* \\ Department of Microbiology and Cell Biology, Indian Institute of Science, Bangalore-560012, India
}

\begin{abstract}
Background: The topological state of DNA is a result of the diverse influences of various topoisomerases present in the cell. Amongst these, DNA gyrase is the only enzyme that is capable of supercoiling DNA. In all the eubacterial cells tested so far, DNA gyrase has proved to be essential for survival. We have earlier cloned $\mathrm{gyr}$ genes from Mycobacterium smegmatis. Unlike the situation in Escherichia coli, genes encoding the two subunits of gyrase are present as a contiguous stretch in the $M$. smegmatis genome.
\end{abstract}

Results: We have demonstrated that the two subunits are encoded by a single dicistronic message, with the transcriptional start site mapping 57 base pairs upstream of the putative translational start of the $g y r B$ ORF. The $g y r$ promoter is specific to $M$. smegmatis and does not function in $E$. coli. We have

\section{Introduction}

DNA in eubacterial cells is negatively supercoiled. The level of supercoiling of the genome is known to influence practically all processes that involve DNA as a substrate-replication, transcription and recombination (Wang 1985, 1996 and references therein). Supercoiling is known to correlate with an increased rate of transcription initiation and a greater number of transcribing complexes; consistent with the observation that binding of the RNA polymerase leads to an unwinding of the double helix in the open complex. Thus, the negative supercoiling stimulates transcription in general. The net level of DNA supercoiling in the cell is a result of the opposing influences of the

Communicated by: Akira Ishihama

* Correspondence: E-mail: vraj@cge.iisc.ernet.in shown that the synthesis of DNA gyrase in $M$. smegmatis is induced by novobiocin-a known inhibitor of gyrase. Short fragments encompassing the promoter region, when cloned in a promoter selection vector, do not show any response to changes in supercoil levels. Larger fragments show a supercoil sensitive behaviour, as seen in the genomic context.

Conclusions: The gene structure and the transcriptional organization of the $g y r$ operon suggest an overall regulatory scheme that is unique to mycobacteria. In contrast to $E$. coli, promoter and regions in its vicinity are not sufficient to confer supercoil sensitivity. Promoter distal regions$600 \mathrm{bp}$ downstream of the promoter-appear to be necessary for relaxation-stimulated transcription in M. smegmatis.

relaxation brought about by topoisomerases I and IV on the one hand and the supercoiling activity of DNA gyrase on the other (Pruss et al. 1982; Richardson et al. 1984; Zechiedrich et al. 1997).

DNA gyrase is a heterotetrameric protein with two types of subunits-GyrA and GyrB. It is the only enzyme which is capable of introducing negative supercoils into DNA. The genes encoding the two subunits are widely separated in the Escherichia coli genome (Bachmann 1987). Since DNA gyrase is involved in increasing the supercoiling of DNA, it is not surprising that the expression of the gyr genes is induced by the relaxation of the DNA template (Menzel \& Gellert 1983). Relaxation stimulated transcription (RST) provides a convenient strategy for the cell to homeostatically maintain the level of supercoiling.

An analysis of the $g \gamma r A$ and $g \gamma r B$ loci of $E$. coli has shown that the sensitivity of the gyr genes to 
A

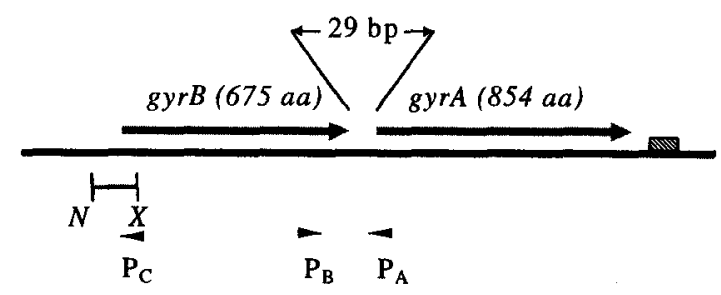

B

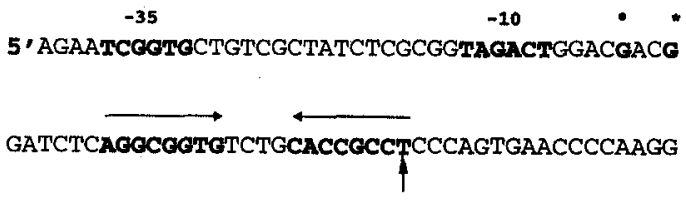

AGACGCGTCCGACGTGCHGCCCAGAAGACAMT 3'

$\begin{array}{lllllllll} & \mathbf{A} & \mathbf{A} & \mathbf{Q} & \mathbf{K} & \mathbf{N} & \mathbf{N}\end{array}$

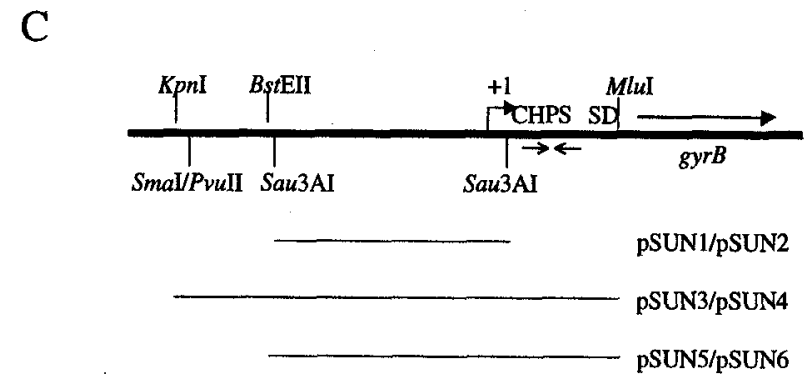

Figure 1 (A) Organization of gyr genes in $M$. smegmatis. N-X represents the NruI-XhoI fragment used for S1 nuclease analysis. The position of various primers discussed in the text is indicated by arrowheads. The filled box indicates the position of the putative transcription terminators; (B) Promoter elements upstream of the start site. The start site mapped by primer extension (*) and by S1 nuclease analysis $(\bullet)$ are shown. The CHPS $(\rightarrow \sqcup)$ is shown along with the primer extension products mapping near it (†); (C) Partial restriction map of the region around the promoter along with short fragments cloned into pSD7. The position of the CHPS is shown as $\rightarrow \leftarrow$.

supercoiling is an intrinsic property of DNA elements in and around the promoter, particularly the -10 region itself (Menzel \& Gellert 1987a,b; Straney et al. 1994). Carty \& Menzel (1990) have also implied a role for a trans factor(s) in RST, which could be titrated out in vitro. Despite such analyses, a clear molecular mechanism for RST has not emerged. In addition, the gyr genes are certainly not the only genes which exhibit RST. Many other promoters have also been shown to respond similarly to changes in supercoiling (Jovanovich \& Lebowitz 1987; Urios et al. 1990; O’Byrne et al. 1992; Kohno et al. 1994; Wu \& Dutta 1995).

The present work describes our analysis of $g y r$ genes from Mycobacterium smegmatis-their organization and regulation. $M$. smegmatis is a fast growing nonpathogenic member of the genus Mycobacterium. It has been used as a model system for analysing the molecular biology and biochemistry in mycobacteria for over three decades (McFadden 1990). Earlier, we have cloned the genes encoding DNA gyrase from $M$. smegmatis (Madhusudan \& Nagaraja 1995). Here we show that the two genes are part of a single operon, with the transcription start site located upstream of the $g y r B$ gene. The gyr promoter functions only in mycobacteria and not in $E$. coli. The gyr genes are induced when the cells are treated by novobiocin-a known inhibitor of DNA gyrase. Our results imply, unlike the situation in E. coli, that promoter distal regions are essential for RST in $M$. smegmatis.

\section{Results}

\section{Organization of the gyr genes in M. smegmatis}

In contrast to the organization in $E$. coli, the $g \gamma r A$ and gyrB genes are present on a single contiguous stretch in $M$. smegmatis (Fig. 1A). The gyrB gene is present upstream of $g \gamma r A$, with a short intergenic region of 29 nucleotides (Madhusudan \& Nagaraja 1995). An analysis of the sequence in and around the gyr genes showed the presence of putative promoter elements upstream of $g \gamma r B$ and strong rho-independent transcription terminator-like sequences downstream of $g \gamma r A$. The short intergenic region was devoid of promoter or 

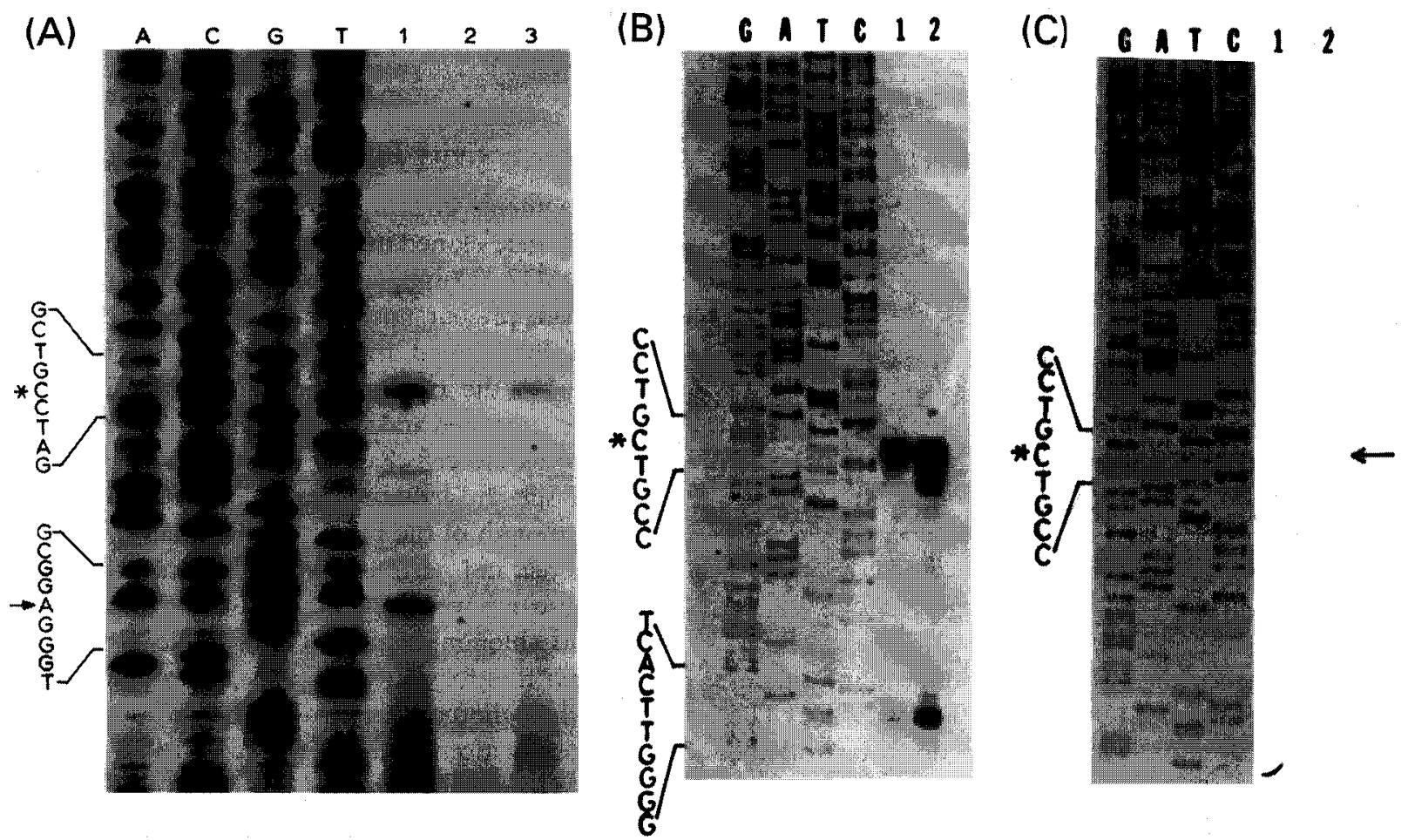

Figure 2 Identification of the transcription start site. (A) Primer extension: Lane 1, Reaction at $42^{\circ} \mathrm{C}$ after denaturation at $70^{\circ} \mathrm{C}$; lanes 2 and 3 , at $50^{\circ} \mathrm{C}$ after denaturation at $95^{\circ} \mathrm{C}$. Lanes 1 and 3, reaction with RNA isolated from cells treated with novobiocin; lane 2 , from untreated cells. All reactions were performed with $10 \mu \mathrm{g}$ of RNA and 10 pmoles of end-labelled primer $\mathrm{P}_{\mathrm{C}}$ and $200 \mathrm{U}$ of Superscript II reverse transcriptase (B and C) S1 nuclease analysis. $300 \mathrm{mg}$ of RNA was co-precipitated and denatured with $5^{\prime}$ end labelled $N r u \mathrm{I}-X h \mathrm{I}$ fragment shown in Fig. 1A. After hybridization at $65^{\circ} \mathrm{C}$ for $16-20$ h the samples were treated with $400 \mathrm{U}$ (lane 1 ) and $200 \mathrm{U}$ (lane 2) of S1 nuclease for $45 \mathrm{~min}$ at $37^{\circ} \mathrm{C}$. (B) Hybridization by rapid cooling to $65^{\circ} \mathrm{C}$. (C) Hybridization by slow cooling to $65^{\circ} \mathrm{C}$. The dideoxy-nucleotide sequencing ladders $(\mathrm{G}, \mathrm{A}, \mathrm{T}$ and $\mathrm{C})$ are shown.

terminator-like sequences, thus suggesting a dicistronic arrangement. A RT-PCR analysis of $M$. smegmatis RNA with primers (Fig. 1A) specific to gyrA $\left(\mathrm{P}_{\mathrm{A}}\right)$ and gyrB $\left(\mathrm{P}_{\mathrm{B}}\right)$ showed an amplification of a $470-\mathrm{bp}$ product encompassing the intergenic region, proving that the two genes are part of a single dicistronic message. Primer extension analyses only showed the presence of a start site upstream of $g y r B$, in agreement with the above conclusion (see next section).

\section{Mapping the transcription start site of the $g y r$ mRNA}

To identify the promoter elements upstream of $g y r B$, we determined the $5^{\prime}$ start site of the gyr mRNA by both primer extension and $\mathrm{S} 1$ nuclease analysis. Initially, when primer extension was carried out at $42{ }^{\circ} \mathrm{C}$, two products were generated (Fig. 2A, lane 1), which could be attributed to the following reasons: (i) presence of two promoters, (ii) processing of the full-length message, or (iii) some local secondary structure in the RNA. The third possibility seems most likely since only the longer product was generated when the extension was performed at $50^{\circ} \mathrm{C}$ (Fig. 2A, lane 3). Under these conditions, fewer intramolecular structures would be formed. These experiments were carried out with RNA isolated from cells treated with novobiocin. Novobiocin is a known inhibitor of gyrase (Gellert et al. 1976) and, by virtue of the inhibition, causes relaxation of the DNA inside the cell (Drlica \& Snyder 1978). In turn, relaxation has been shown to induce gyrase expression in E. coli (Menzel \& Gellert 1983). We find a similar induction of transcription in $M$. smegmatis cells (Fig. 2A, compare lanes 2 and 3). The reactions in all three lanes were carried out with equal amounts of RNA. Similar results were obtained by $S 1$ nuclease analysis, although the +1 site mapped a few bases upstream with respect to that obtained by primer extension (Fig. 2B,C). This is not surprising considering the heterogeneity in cleavage at the 
Table 1 Promoter activity in E. coli and M. smegmatis

\begin{tabular}{|c|c|c|c|c|c|c|}
\hline \multirow[b]{3}{*}{ Plasmid } & \multirow{2}{*}{\multicolumn{2}{|c|}{$\frac{\text { E. coli }}{\text { c.f.u. }\left(\times 10^{6}\right)}$}} & \multirow{3}{*}{$\begin{array}{l}\text { - CAT } \\
\text { activity }\end{array}$} & \multirow{2}{*}{\multicolumn{2}{|c|}{$\frac{\text { M. smegmatis }}{\text { c.f.u. }\left(\times 10^{6}\right)}$}} & \multirow{3}{*}{$\begin{array}{l}\text { - CAT } \\
\text { activity }\end{array}$} \\
\hline & & & & & & \\
\hline & $\mathrm{Kn}^{\mathrm{r}}$ & $\mathrm{Kn}^{\mathrm{r}} \mathrm{Cm}^{\mathrm{r}}$ & & $\mathrm{Kn}^{\mathrm{r}}$ & $\mathrm{Kn}^{\mathrm{r}} \mathrm{Cm}^{\mathrm{r}}$ & \\
\hline pSD7 & 3.2 & 0 & $0.2 \pm 0.1$ & 5.1 & 0 & $0.3 \pm 0.1$ \\
\hline pSUN1 & 3.5 & 0 & $0.3 \pm 0.1$ & 4.0 & 4.1 & $7.0 \pm 0.4$ \\
\hline pSUN2 & 2.4 & 0 & $0.1 \pm 0.1$ & 5.8 & 0 & $0.7 \pm 0.2$ \\
\hline pSUN3 & 3.0 & 0 & $0.2 \pm 0.1$ & 6.3 & 6.2 & $24.7 \pm 1.2$ \\
\hline pSUN4 & 2.3 & 0 & $0.3 \pm 0.1$ & 6.1 & 0 & $0.7 \pm 0.2$ \\
\hline pSUN5 & 3.0 & 0 & $0.2 \pm 0.1$ & 5.5 & 5.3 & $21.4 \pm 1.1$ \\
\hline pSUN6 & 3.6 & 0 & $0.1 \pm 0.1$ & 5.2 & 0 & $0.9 \pm 0.2$ \\
\hline
\end{tabular}

CAT specific activity was calculated as described in Experimental procedures.

junction between the RNA-DNA duplex and singlestranded DNA by S1 nuclease (Berk 1989). The putative -10 and -35 regions upstream of the transcription start site are shown in Fig. 1B. Interestingly, a palindromic sequence (cruciform/hairpin potential sequence, CHPS) is located 10 nucleotides downstream of the transcription start site (Fig. 1B). Such sequences could adopt a hairpin-like structure in mRNA and/or extrude out as a cruciform DNA in a supercoil-dependent manner (Lilley 1985). Such a structure would explain the second extension product or protected fragment that was detected in the above experiments. The theoretical estimate for the free energy of melting of the hairpin is $-17.30 \mathrm{kcal} /$ $\mathrm{mol}$ and therefore once formed, the structure would be extremely stable. A similar primer extension analysis with $\mathrm{P}_{\mathrm{A}}$ failed to detect any $g \gamma r A$-specific transcriptional start site, again implying that transcription is driven from the solitary promoter located upstream of grrB.

\section{Promoter activity in E. coli and M. smegmatis}

Short fragments encompassing the putative promoter (Fig. 1C) were cloned in the promoter selection shuttle vector pSD7 (Dasgupta et al. 1993) at the unique BamHI site present upstream of a promoterless CAT gene. If the cloned fragment contains a functional promoter in the correct orientation, the CAT gene would be expressed and would confer chloramphenicol resistance to the cell. Earlier workers have shown that the CAT-specific activity in such constructs reflects the relative strength of the promoter (Gorman et al. 1982). Both $E$. coli and $M$. smegmatis cells transformed with these constructs were tested for resistance to kanamycin $\left(\mathrm{Kn}^{\mathrm{r}}\right)$ and chloramphenicol $\left(\mathrm{Cm}^{\mathrm{r}}\right)$ (Table 1). None of the E. coli transformants was resistant to chloramphenicol, while the constructs with the promoter in the correct orientation conferred resistance to $M$. smegmatis cells. CAT specific activity in crude cell extracts essentially paralleled the result (Table 1), indicating that the promoter is specific to mycobacterium and does not function in $E$. coli. These findings are supported by the observation that the $M$. smegmatis genes did not complement the E. coli gyrA and gyrB temperature sensitive strains when present under their native promoter. On the other hand, when the $M$. smegmatis gyr $A$ was expressed under $\mathrm{P}_{\mathrm{trc}}$, and $g y r B$ under $\mathrm{P}_{\mathrm{lac}}$, they rescued the respective $E$. coli mutants. Interestingly, the cells harbouring pSUN3 and pSUN5 show 3- to 3.5-fold higher CAT activity than those harbouring pSUN1 when the cells were grown in LB medium, and the difference increased to six to sevenfold in YK medium. There was a further increase

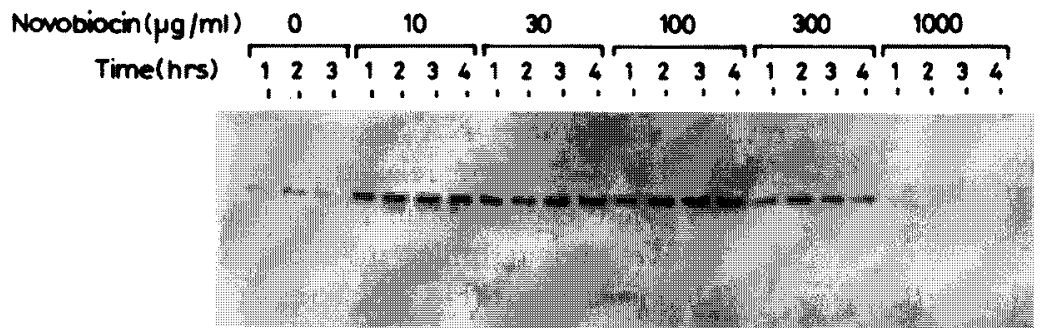

Figure 3 Immunoblot analysis of protein extracts from $M$. smegmatis. Cells were grown to mid-log phase, split into $5 \mathrm{~mL}$ aliquots and treated with different amounts of novobiocin. Cells were harvested at different times and frozen at $-70^{\circ} \mathrm{C}$. Prior to the immunoblot, the cells were thawed, washed and sonicated. The protein extracts were quantified and $6 \mu \mathrm{g}$ of protein extract was loaded on each lane. The protein was transferred on to a PVDF membrane, probed with anti-GyrA polyclonal antibodies and developed with anti-rabbit IgG-HRP conjugate using hydrogen peroxide and TMB. 
(40-fold) when the cells were grown in Starvation Medium (YK medium with $0.5 \%$ glycerol instead of $2 \%$ ). It should be pointed out that pSUN1 lacks the cruciform/hairpin potential sequence (CHPS) and putative Shine-Dalgarno (SD) sequence which are present in the other two constructs (Fig. 1C). Both these elements have been shown to stabilize the downstream mRNA against degradation in E. coli (Hansen et al. 1994; Agaisse \& Lereclus 1996).

\section{Analysis of RST at the genomic level}

To establish RST in $M$. smegmatis, we assessed changes in steady-state levels of the GyrA protein. Immunoblot analysis using polyclonal antibodies raised against $M$. tuberculosis GyrA protein showed that DNA gyrase was induced threefold on treatment with novobiocin (Fig. 3). The response of cells reached a maximum within $4-5 \mathrm{~h}$ of treatment with the drug. The response of cells appears to be biphasic with respect to drug concentrations. At low to intermediate concentrations of the drug $(10-300 \mu \mathrm{g} / \mathrm{mL})$, there is an increase in the steady-state level of GyrA. At higher concentrations $(1 \mathrm{mg} / \mathrm{mL})$, the operon appears to be refractory to the drug, probably because the cells die even before they mount an adaptive response. Thus, we see that treatment with novobiocin leads to an increase in the gyr message (Fig. 2A, compare lanes 2 and 3) and this leads to an increase in steady state levels of the gyr proteins.

\section{Role of promoter proximal regions in RST}

The presence of a cruciform potential sequence near the $5^{\prime}$ end of the gyr message suggests a possible mechanism for RST in M. smegmatis. Cruciforms in DNA have been shown to extrude in a supercoil dependent manner (Lilley 1985). In addition, cruciform structures overlapping promoter elements or within the gene can down-regulate gene expression (Horwitz \& Loeb 1988; Bagga et al. 1990). Our hypothesis was that the CHPS would extrude out to form a cruciform at a high supercoil density and inhibit transcription elongation. On a relaxed template, the sequence would collapse back into B-DNA conformation and allow the transcription machinery to go through. Thus, the CHPS would provide a relatively simple mechanism for the cell to sense supercoiling and couple it to transcription regulation. To test whether the promoter itself or regions in its immediate vicinity, including the CHPS, were responsible for RST, $M$. smegmatis cells harbouring the three short constructs (pSUN1, 3 and 5, Fig. 1C) were tested for their response to novobiocin. If

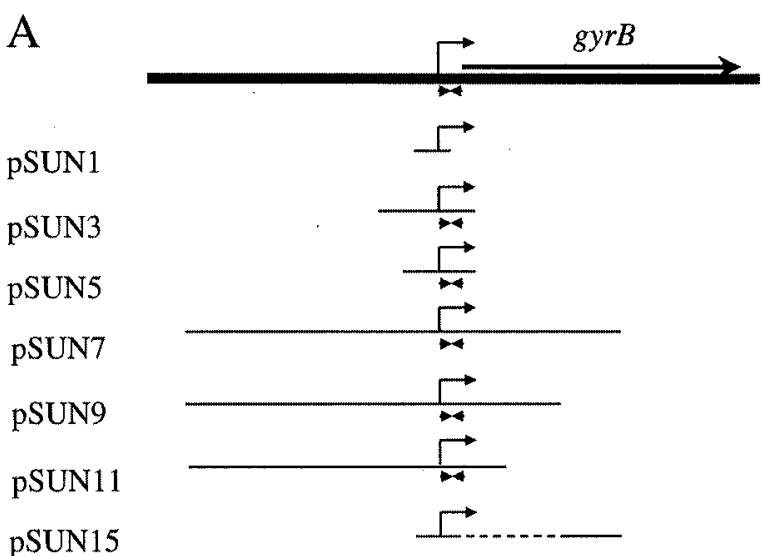

B

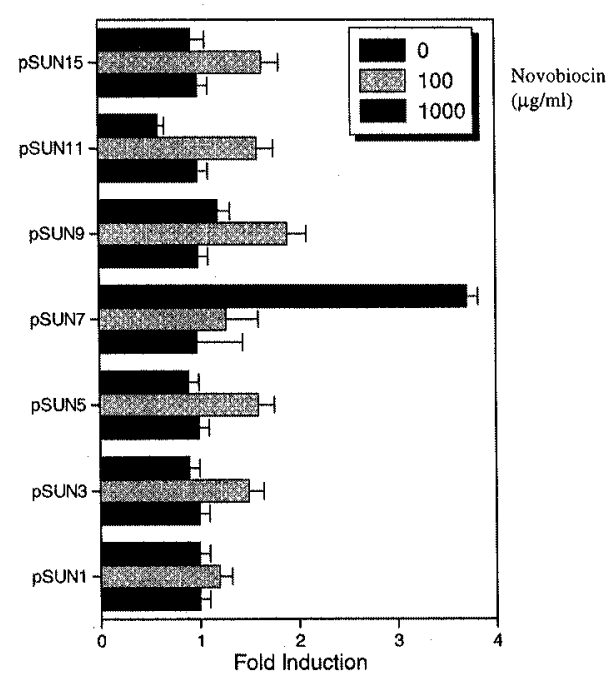

Figure 4 RST in the plasmid context. (A) All the constructs have been shown schematically. The transcription start site $(\mapsto)$ and CHPS $(\rightarrow \leftarrow)$ are indicated. (B) Fold induction of CAT activity of cells harbouring various constructs after treatment with different amounts of novobiocin $(\mu \mathrm{g} / \mathrm{mL})$ for $4 \mathrm{~h}$.

the RST were operational, it would be reflected in an increase in CAT specific activity. We found that there was no significant increase in CAT specific activity in any of these shorter constructs-comprising promoter and promoter proximal regions (Fig. 4B). We tested these cells with a large range of novobiocin concentrations $(10 \mu \mathrm{g} / \mathrm{mL}$ to $1000 \mu \mathrm{g} / \mathrm{mL})$ to ensure that we were not missing out a particular window of sensitivity. The steady state levels of GyrA in these transformants showed a similar increase, as seen in Fig. 3. Quantitative ELISA revealed that induction of the genomic copy was unaffected by the presence of the short constructs. 


\begin{tabular}{llll}
\hline Gene/promoter & -35 & -10 & Reference \\
\hline ask & CCCACG & ACGCGT & Cirillo et al. (1994) \\
acetamidase & TTGACT & TATATT & Mahenthiralingam et al. (1993) \\
$r m B$ & TTGACT & TAACTT & EMBL acc. no. U09862 \\
S4 & GACCTT* & TATAAG & Bashyam et al. (1996) \\
S16 & GCTTCG* $^{*}$ & TATAAT & Bashyam et al. (1996) \\
S18 & TCATTG* & TAAAGT & Bashyam et al. (1996) \\
S19 & AAAGGC* & TAGTAT & Bashyam et al. (1996) \\
$g y r$ & TCGGTG & TAGACT & This work \\
\hline
\end{tabular}

Table 2 Compilation of strong promoters from $M$. smegmatis

* Not proposed by Bashyam et al; extrapolated from the sequence.

\section{Role of distal regions in RST}

There could be many reasons for the failure of short promoter fragments to respond to novobiocin in the plasmid context (see Discussion). One explanation is that the plasmid constructs lacked some DNA element that was located further away from the promoter that is essential for RST. To test this possibility, we created a construct containing a 2.5-kb BamHI fragment (pSUN7) encompassing the promoter (Fig. 4A). As compared to the shorter constructs, pSUN7 is significantly stimulated by novobiocin (Fig. 4B). The 3.5-fold stimulation is comparable to the induction obtained in the genomic context. These cells respond only at a level of $1 \mathrm{mg} / \mathrm{mL}$ of novobiocin, probably because pSUN7 contains the $\mathrm{N}$-terminal half of GyrB which is responsible for binding novobiocin. The overexpression of truncated fragments of $\mathrm{GyrB}$ have been shown to confer resistance to novobiocin in $E$. coli (del Castillo et al. 1991). To further delineate the elements that are responsible for RST, we made sequential deletions in the downstream region (pSUN9 and pSUN11; Fig. 4A). Both these deletions significantly lower the response to changes in supercoil levels (Fig. 4B). These experiments suggest that DNA elements present $600 \mathrm{bp}$ downstream of the promoter play an essential role in RST in mycobacteria. However, the downstream element along with the minimal promoter region (pSUN15; Fig. 4A) is not sufficient to respond to novobiocin (Fig. $4 \mathrm{~B}$ ).

\section{Discussion}

We have presented the first clear demonstration of a dicistronic organization of the gyr genes in any species. The transcription is driven from a single promoter located upstream of $g y r B$. The promoter is specific to mycobacteria and does not function in E. coli. We find that RST, although it is operational in $M$. smegmatis, appears to employ a different mechanism from E. coli.

The positioning of regulatory elements in the gyr locus points towards a co-ordinated expression of the two genes. RT-PCR with primers specific to $g y r A$ and gyrB demonstrates that the genes are transcribed as a single operon. In addition, the only detectable promoter is located upstream of the $g y r B$ (Fig. 2), while rhoindependent terminator-like sequences are present exclusively downstream of gyrA. The short intergenic region lacks any such features. We find no transcription start site upstream of $g y r A$. Furthermore, the $g y r B$ gene has a strong SD sequence (AGGAGA) upstream of a weak start codon (GTG), while gyrA has a poor SD sequence (AGGAT'T), but employs the more efficient ATG as the start codon. Such an arrangement suggests a translational coupling mechanism that could facilitate the production of equimolar amounts of the two subunits that would be required for making a functional enzyme. The genomic organization of gyr genes in many species also suggests an operon-like arrangement (Sugino \& Bott 1980; Colman et al. 1990; Holmes \& Dyall-Smith 1991; Thiara \& Cundliffe 1993; Madhusudan et al. 1994; Salazar et al. 1996). However, it is noteworthy that in Bacillus subtilis, although the gyrA and gyrB genes are near each other, they are transcribed independently (Lampe \& Bott 1985).

An analysis of the putative promoter elements of the gyr operon of $M$. smegmatis reveals that the -10 region resembles the consensus sequence for the $\sigma^{70}$ promoters of E. coli (Hawley \& McClure 1983) while the -35 region does not. A compilation of strong promoters identified in $M$. smegmatis is shown in Table 2. As can be seen, most of these promoters also show a greater conservation at the -10 region than the -35 . In comparison with the promoters analysed by Dasgupta 
et al. (1993), the gyr promoter is amongst the strongest to be isolated from $M$. smegmatis. The strongest promoter in their study has a CAT specific activity of less than $2500 \mathrm{nmol} / \mathrm{min} / \mathrm{mg}$, while cells harbouring pSUN3 show an activity of about $4300 \mathrm{nmol} / \mathrm{min} / \mathrm{mg}$. Thus, the gyr promoter has the potential to be used for homologous over-expression of genes in mycobacteria.

We have found that the gyr operon in $M$. smegmatis is induced by novobiocin at the transcriptional level (Figs 2A, 3). The presence of a strong CHPS (Fig. 1B) with an 8 base pair stem and a 4 base loop in the $5^{\prime}$ UTR suggested a potential mechanism for RST in $M$. smegmatis. The gyrA gene from Klebsiella pneumoniae also has a cruciform potential sequence which overlaps with the -35 elements in the putative promoter which has been proposed to be involved in RST (Dimri \& Das 1990). Similarly, cruciform potential sequences in the $5^{\prime}$ UTR have been shown to affect transcription elongation (Bagga et al. 1990; Brahmachari et al. 1991). We find that the $5^{\prime}$ untranslated region-including the CHPS-has a positive effect on promoter activity (Table 1) but is not sufficient for the operon to respond to novobiocin (Fig. 4). There could be a multitude of reasons for this observation. Firstly, a much higher level of novobiocin may be required to inhibit the mycobacterial gyrase and induce global relaxation. Secondly, a trans factor(s) may be involved in RST that is titrated out in a multicopy plasmid context. Thirdly, distal regions may be necessary for RST to occur. If the first possibility were true, then, in these cells, there would be no induction at the genomic level. In the second case, the gyr genes at the genomic level would be induced only in cells transformed with the vector pSD7 but not with any of the promoter constructs. The induction of the genomic copy and the results with the longer constructs (Fig. 4) essentially show the crucial role that is played by regions downstream of the promoter. We find DNA elements that are present 600-bp downstream of the promoter are necessary for RST to occur in the plasmid context. However, this region alone is not sufficient to confer sensitivity to supercoiling. The role played by distal elements in $M$. smegmatis may be direct (as a binding site for some trans factor) or indirect (as a modulator of supercoil levels). These results are in sharp contrast to the gyr genes in $E$. coli where the -10 region itself is responsible for RST, although it is devoid of any structure potential sequences (Straney et al. 1994). It is important to reiterate here that although extensive work has gone into localizing the phenomenon of RST to the -10 region of the $g \gamma r$ promoter in $E$. coli, a model at the molecular level is still lacking.
Thus, while RST makes biological sense, mechanistically it remains a mystery wherever it has been studied. It appears that although the phenomenon of autoregulation of gyr genes by sensing global supercoil levels is conserved in different species, the sensing mechanism itself differs. In $E$. coli, special features (if any) in the promoter itself, alone or along with a trans factor(s), seem to be involved in the process. $M$. smegmatis, on the other hand, appears to employ regions distant from the promoter. It is possible that the topological status of distant regions is measured and communicated to the promoter, influencing the transcriptional process itself.

\section{Experimental procedures}

\section{Bacterial strains and plasmids}

All the strains and plasmids used in this study are listed in Table 3. The E. coli strain DH10B was used for all cloning experiments and as the $E$. coli host for the CAT assays. $M$. smegmatis $\mathrm{SN} 2$ was used for the promoter mapping experiments. M. smegmatis $\mathrm{mc}^{2} 155$ was used as the mycobacterial host for all the CAT assays. The $E$. coli cells were grown in Luria-Bertani (LB) medium, while the $M$. smegmatis cells were grown either in modified Youmans and Karlson's medium (Nagaraja \& Gopinathan 1980 ), with $2 \%$ or $0.5 \%$ glycerol, or LB medium supplemented with $0.5 \%$ glycerol and $0.2 \%$ Tween-80. Kanamycin was added at $35 \mu \mathrm{g} / \mathrm{mL}$ where appropriate.

The promoter selection shuttle vector pSD7 (Dasgupta et al. 1993) was used for the promoter analysis. E. coli DH10B cells were transformed by the standard calcium chloride method (Sambrook et al. 1989). M. smegmatis cells were transformed as previously described (Dasgupta $e t$ al. 1993). After transformation, the cells were plated on LB agar containing $0.5 \%$ glycerol with kanamycin $(35 \mu \mathrm{g} / \mathrm{mL})$, either alone or in combination with chloramphenicol $(25 \mu \mathrm{g} / \mathrm{mL})$.

\section{RNA isolation}

For the S1 nuclease analysis, $\log$-phase cultures of $M$. smegmatis SN2 were harvested, either directly or after two hours of treatment with novobiocin $(25 \mu \mathrm{g} / \mathrm{mL})$. The pellet was washed and resuspended in Buffer A $(300 \mathrm{~mm}$ sodium acetate $\mathrm{pH} 4$, $10 \mathrm{~mm}$ EDTA), and extracted with acid phenol at $65^{\circ} \mathrm{C}$. The cell suspension was sonicated to complete the lysis. After centrifugation, the aqueous layer was re-extracted with phenol and chloroform-isoamyl alcohol $(24: 1)$ and the RNA was finally precipitated with 2.5 volumes of ethanol and resuspended in DEPC-treated water. For RT-PCR and the primer extension analysis, RNA was isolated using TRIzol Reagent (Gibco BRL) following the manufacturer's instructions. 
Table 3 Strains and plasmids

\begin{tabular}{|c|c|c|}
\hline Strains/plasmids & Relevant features & Source/reference \\
\hline M. smegmatis $\mathrm{SN} 2$ & Wild-type & Laboratory stock \\
\hline M. smegmatis $\mathrm{mc}^{2} 155$ & High efficiency transformation strain & Snapper et al. (1990) \\
\hline E. coli $\mathrm{DH} 10 \mathrm{~B}$ & High efficiency transformation strain & Laboratory stock \\
\hline E. coli $\mathrm{NH} 647$ & gyrA $^{\text {ts }}$ & M. Gellert \\
\hline E. coli $\mathrm{N} 4177$ & $\mathrm{gyrB}^{\mathrm{ts}} \operatorname{cou}^{\mathrm{r}}$ & N. R. Cozzarelli \\
\hline pSD7 & $\begin{array}{l}\text { E. coli-mycobacteria shuttle promoter-selection vector with a } \\
\text { promoterless CAT gene. }\end{array}$ & Dasgupta et al. 1993; \\
\hline pMN9A & $\begin{array}{l}4.5-\mathrm{kb} \text { genomic fragment containing the upstream, entire gyrB } \\
\text { and part of the gyrA gene in pUC19. }\end{array}$ & Madhusudan \& Nagaraja 1995 \\
\hline pSUN1 & $\begin{array}{l}\text { Derivative of pSD7 with a } 257-\text { bp promoter fragment in the } \\
\text { correct orientation (Figs } 1 C, 4 \text { ) }\end{array}$ & This work \\
\hline pSUN2 & $\begin{array}{l}\text { Same as pSUN1 but with the promoter in the opposite } \\
\text { orientation (Fig. 1C). }\end{array}$ & This work \\
\hline pSUN3 & $\begin{array}{l}\text { Derivative of pSD7 with a } 377-\text { bp promoter fragment in the } \\
\text { correct orientation (Figs 1C, 4). }\end{array}$ & This work \\
\hline pSUN4 & $\begin{array}{l}\text { Same as pSUN3 but with the promoter in the opposite } \\
\text { orientation (Fig. 1C). }\end{array}$ & This work \\
\hline pSUN5 & $\begin{array}{l}\text { Derivative of pSD7 with a } 317-b p \text { promoter fragment in the } \\
\text { correct orientation (Figs 1C, 4). }\end{array}$ & This work \\
\hline pSUN6 & $\begin{array}{l}\text { Same as pSUN5 but with the promoter in the opposite } \\
\text { orientation (Fig. 1C). }\end{array}$ & This work \\
\hline pSUN7 & $\begin{array}{l}\text { Derivative of } \mathrm{pSD} 7 \text { with a } 2.5-\mathrm{kb} \text { promoter fragment in the } \\
\text { correct orientation. The fragment contains } 1.5 \mathrm{~kb} \text { upstream and } \\
1 \mathrm{~kb} \text { downstream of the promoter (Fig. } 4 \text { ). }\end{array}$ & This work \\
\hline pSUN9 & $\begin{array}{l}\text { Derivative of pSUN7 with the last } 390 \text { bp deleted from the } \\
\text { downstream segment (Fig. 4). }\end{array}$ & This work \\
\hline pSUN11 & $\begin{array}{l}\text { Derivative of pSUN7 with the last } 790 \mathrm{bp} \text { deleted from the } \\
\text { downstream segment (Fig. 4). }\end{array}$ & This work \\
\hline pSUN15 & $\begin{array}{l}\text { Derivative of pSUN1 with the last } 390 \mathrm{bp} \text { from the downstream } \\
\text { segment of pSUN7 added (Fig. 4). }\end{array}$ & This work \\
\hline
\end{tabular}

\section{Primer extension and RT-PCR}

Primer extension was performed as per the manufacturer's instructions using Superscript II reverse transcriptase (Gibco $\mathrm{BRL}$ ) using primers $\mathrm{P}_{\mathrm{C}}$ or $\mathrm{P}_{\mathrm{A}}$. The primers were previously endlabelled using $\gamma-\mathrm{P}^{32}$-ATP $(>5000 \mathrm{Ci} / \mathrm{mol}$, Amersham) and T4 polynucleotide kinase (Gibco BRL). For RT-PCR, first strand synthesis was performed with Superscript II reverse transcriptase (RT) using $P_{A}$. The PCR was carried out with $P_{A}$ and $P_{B}$ using Taq polymerase in two parts-for the first five cycles, the annealing was at $40^{\circ} \mathrm{C}$, followed by 25 cycles with annealing at $55^{\circ} \mathrm{C}$. $\mathrm{P}_{\mathrm{A}}: 5^{\prime}$ TCG ACC GGT TCG ATC CGG TC $3^{\prime}$ $P_{\mathrm{B}}: 5^{\prime}$ GTT GTT GGG CCG GTT CAT GAA GC $3^{\prime}$ $P_{C}: 5^{\prime}$ TCG AGA ATG GTG ATG GAA TCG GC $3^{\prime}$

\section{S1 nuclease analysis}

The S1 nuclease mapping method was adapted from Sharp et al. (1980). A 600-bp NruI-XhoI fragment spanning the putative start codon for $g y r B$ was used as the probe (Fig. 1). This fragment was radioactively labelled at the $X h o l$ site using $\gamma-{ }^{32} \mathrm{P}-\mathrm{ATP}$ and T4 polynucleotide kinase. Three hundred $\mu \mathrm{g}$ of RNA were co-precipitated with $2 \times 10^{5}$ c.p.m. and heated at $97^{\circ} \mathrm{C}$ for $10 \mathrm{~min}$ in $25 \mu \mathrm{L}$ of hybridization buffer $(40 \mathrm{~mm}$ piperazine$\mathrm{N}, \mathrm{N}^{\prime}$-bis(2-ethanesulphonic acid) $\mathrm{pH} 6.5,400 \mathrm{~mm}$ sodium chloride, $1 \mathrm{~mm}$ EDTA, $80 \%$ formamide) and incubated at $65^{\circ} \mathrm{C}$ for $16-20 \mathrm{~h}$. $400 \mu \mathrm{L}$ of $\mathrm{S} 1$ nuclease buffer $(30 \mathrm{~mm}$ sodium acetate $\mathrm{pH} 4.5,300 \mathrm{~mm}$ sodium chloride, $1 \mathrm{~mm}$ zinc sulphate) was added and $200 \mu \mathrm{L}$ aliquots were digested with different concentrations of $\mathrm{S} 1$ nuclease $(200 \mathrm{U}$ and $400 \mathrm{U}$ ) for $45 \mathrm{~min}$ at $37^{\circ} \mathrm{C}$. The protected fragments were extracted with phenol:chloroform:isoamyl alcohol $(25: 24: 1)$ and precipitated. The pellet was dissolved in formamide loading dye and analysed on an $8 \mathrm{M}$ urea- $6 \%$ polyacrylamide gel. The DNA sequence ladder was generated using the primer $\mathrm{P}_{\mathrm{C}}$-designed to the $\mathrm{XhoI}$ end.

\section{CAT assays and novobiocin treatment}

For determination of the CAT-specific activity, a single colony was inoculated into $3 \mathrm{~mL}$ of medium and grown to mid-log 
phase. The cells were harvested, washed with an equal volume of Buffer B (250 mm Tris- $\mathrm{HCl}, \mathrm{pH} 8)$ and resuspended in 1/4 volume of the same buffer. The cells were sonicated and centrifuged at $15000 \mathrm{~g}$ for $15 \mathrm{~min}$ at $4^{\circ} \mathrm{C}$. An appropriate dilution of the supernatant was assayed for CAT activity. The reaction contained $100 \mu \mathrm{M}{ }^{14} \mathrm{C}$-chloramphenicol $(5 \mathrm{mCi} / \mathrm{mmol})$ and $300 \mu \mathrm{g} / \mathrm{mL}$ acetyl coenzyme $\mathrm{A}$ in $250 \mathrm{~mm}$ Tris- $\mathrm{HCl}(\mathrm{pH} 8)$. The reaction was carried out at $37^{\circ} \mathrm{C}$ for $30 \mathrm{~min}$ and stopped with 10 volumes of cold ethyl acetate. The organic layer was dried. Samples were resuspended in a minimal volume of ethyl acetate and resolved on a fluorescent silica thin layer chromatography (TLC) plate with chloroform:methanol (95:1). After autoradiography, the region corresponding to the products and substrate was cut out and its radioactivity was measured in a liquid scintillation counter. The CAT activity was calculated as the percentage of the substrate converted to monoacetylated form in 30 min at $37^{\circ} \mathrm{C}$ per $100 \mathrm{ng}$ of the protein.

For induction by novobiocin, cells were grown to mid-log phase in $30 \mathrm{~mL}$ of starvation medium. The cultures were distributed into six tubes with $5 \mathrm{~mL}$ in each, treated with different concentrations of novobiocin, and allowed to grow further. $900 \mu \mathrm{L}$ aliquots were taken every hour and frozen in liquid nitrogen at $-70^{\circ} \mathrm{C}$. When required, these aliquots were thawed on ice and processed as described above.

\section{Immunoblot analysis and ELISA}

For immunoblotting, $6 \mu \mathrm{g}$ of the crude cell extract was resolved on a $1 \%$ SDS- $8 \%$ PAGE and electroblotted on to a polyvinyldene difluoride membrane. The blot was probed with polyclonal antibodies $(1: 5000)$ raised in rabbit against $M$. tuberculosis GyrA. The blot was developed with secondary antibody conjugated with horseradish peroxidase $(1: 2000$, Sigma) and 3-amino-9ethylcarbazole (Sigma). For the ELISA, $10 \mu \mathrm{g}$ of the crude cell extract was coated on to each well. The plates were probed as described above and developed with tetramethylbenzadene.

\section{Acknowledgements}

The authors thank M. Gellert for the gyrA ${ }^{\text {ts }}$ strain, NH647, and N. Cozzarelli for gyrB ${ }^{\text {ts }}$ strain N4177, A. K. Tyagi for the vector pSD7. We acknowledge $\mathrm{K}$. Madhusudan for the S1 nuclease analysis; U.H. Manjunatha for polyclonal antibodies; and $M$. Chatterji for helpful suggestions. We thank A. Ishihama and the reviewers for their invaluable suggestions. The work is supported by grants from the Department of Biotechnology and Council for Scientific and Industrial Research, Government of India.

\section{References}

Agaisse, H. \& Lereclus, D. (1996) STAB-SD: a Shine-Dalgarno sequence in the $5^{\prime}$ untranslated region is a determinant of mRNA stability. Mol. Microbiol. 20, 633-643.

Bachmann, B.J. (1987) Linkage map of Escherichia coli K-12, edition 7. In Escherichia Coli and Salmonella Typhimurium (ed.
F.C. Neidhardt), pp. 807-877. Washington: American Society for Microbiology.

Bagga, R., Ramesh, N. \& Brahmachari, S.K. (1990) Supercoilinduced unusual DNA structures as transcriptional block. Nucl. Acids Res. 18, 3363-3369.

Bashyam, M.D., Kaushal, D., Dasgupta, S.K. \& Tyagi, A.K. (1996) A study of the mycobacterial transcriptional apparatus: identification of novel features in promoter elements. $J$. Bacteriol. 178, 4847-4853.

Berk, A.J. (1989) Characterisation of RNA molecules by S1 nuclease analysis. Meth. Enzymol. 180, 334-347.

Brahmachari, S.K., Sarkar, P.S., Balagurumoorthy, P., Burma, P.K. \& Bagga, R. (1991) Synthetic gene design to investigate the role of cis-acting DNA structural elements in regulation of gene expression in vivo. Nucl. Acids Symp. Ser. 24, 163-166.

Carty, M. \& Menzel, R. (1990) Inhibition of DNA gyrase in an in vitro transcription-translation system stimulates $g y r A$ expression in a DNA concentration dependent manner. J. Mol. Biol. 214, 397-406.

Cirillo, J.D., Weisbrod, T.R., Pascopella, L., Bloom, B.R. \& Jacobs, W.R. Jr (1994) Isolation and characterization of the aspartokinase and aspartate semialdehyde dehydrogenase operon from mycobacteria. Mol. Microbiol. 11, 629-639.

Colman, S.D., Hu, P.C. \& Bott, K.F. (1990) Mycoplasma pneumoniae DNA gyrase genes. Mol. Microbiol. 4, 1129-1134.

Dasgupta, S.K., Bashyam, M.D. \& Tyagi, A.K. (1993) Cloning and assessment of mycobacterial promoters by using a plasmid shuttle vector. J. Bacteriol. 175, 5186-5192.

del Castillo, I., Vizan, J.L., Rodriguez-Sainz, M.C. \& Moreno, F. (1991) An unusual mechanism for resistance to the antibiotic coumermycin A1. Proc. Natl. Acad. Sci. USA 88, 8860-8864.

Dimri, G.P. \& Das, H.K. (1990) Cloning and sequence analysis of gyrA gene of Klebsiella pneumoniae. Nucl. Acids Res. 18, $151-156$.

Drlica, K. \& Snyder, M. (1978) Superhelical Escherichia coli DNA: relaxation by coumermycin. J. Mol. Biol. 120, 145-154.

Gellert, M., O'Dea, M.H., Itoh, T. \& Tomizawa, J. (1976) Novobiocin and coumermycin inhibit DNA supercoiling catalyzed by DNA gyrase. Proc. Natl. Acad. Sci. USA 73, 4474-4478.

Gorman, C.M., Moffat, L.F. \& Howard, B.H. (1982) Recombinant genomes which express chloramphenicol acetyltransferase in mammalian cells. Mol. Cell. Biol. 2, 1044-1051.

Hansen, M.J., Chen, L.-H., Fejzo, M.L.S. \& Belasco, J.G. (1994) The omp $A 5^{\prime}$ untranslated region impedes a major pathway for mRNA degradation in Escherichia coli. Mol. Microbiol. 12, 707-716.

Hawley, D.K. \& McClure, W.R. (1983) Compilation and analysis of Escherichia coli promoter DNA sequences. Nucl. Acids Res. 11, 2237-2255.

Holmes, M.L. \& Dyall-Smith, M.L. (1991) Mutations in DNA gyrase result in novobiocin resistance in halophilic archaebacteria. J. Bacteriol. 173, 642-648.

Horwitz, M.S. \& Loeb, L.A. (1988) An E. coli promoter that regulates transcription by DNA superhelix-induced cruciform extrusion. Science 241, 703-705.

Jovanovich, S.B. \& Lebowitz, J. (1987) Estimation of the effect of coumermycin A1 on Salmonella typhimurium promoters by random operon fusions. J. Bacteriol. 169, 4431-4435.

Kohno, K., Yasuzawa, K., Goshima, N., Tanaka, H. \& Imamoto, F. (1994) Autoregulation of transcription of the hupA gene in 
Escherichia coli: evidence for steric hindrance of the functional promoter domains induced by HU. J. Biochem. (Tokyo) 115, 1113-1118.

Lampe, M.F. \& Bott, K.F. (1985) Genetic and physical organisation of the cloned gyrA and gyrB genes of Bacillus subtilis. J. Bacteriol. 162, 78-84.

Lilley, D.M.J. (1985) The kinetic properties of cruciform extrusion are determined by DNA base-sequence. Nucl. Acids Res. 13, 1443-1465.

Madhusudan, K. \& Nagaraja, V. (1995) Mycobacterium smegmatis DNA gyrase: cloning and overexpression in Escherichia coli. Microbiology 141, 3029-3037.

Madhusudan, K., Ramesh, V. \& Nagaraja, V. (1994) Cloning and sequence analysis of DNA gyrase genes from Mycobacterium tuberculosis. Curr. Sci. 66, 664-667.

Mahenthiralingam, E., Draper, P., Davis, E.O. \& Colston, M.J. (1993) Cloning and sequencing of the gene which encodes the highly inducible acetamidase of Mycobacterium smegmatis. $J$. Gen. Microbiol. 139, 575 -583.

McFadden, J. (1990). Molecular Biology of the Mycobacteria. London: Academic Press.

Menzel, R. \& Gellert, M. (1983) Regulation of the genes for $E$. coli DNA gyrase: homeostatic control of DNA supercoiling. Cell 34, 105-113.

Menzel, R. \& Gellert, M. (1987a) Fusions of the Escherichia coli $g y r A$ and $g y r B$ control regions to the galactokinase gene are inducible by coumermycin treatment. J. Bacteriol. 169, $1272-1278$.

Menzel, R. \& Gellert, M. (1987b) Modulation of transcription by DNA supercoiling: deletion analysis of the Escherichia coli gyrA and gyrB promoters. Proc. Natl. Acad. Sci. USA 84, 4185-4189.

Nagaraja, V. \& Gopinathan, K.P. (1980) Requirement of calcium ions in Mycobacteriophage I3 DNA infection and propagation. Arch. Microbiol. 124, 249-254.

O'Byrne, C.P., NiBhriain, N. \& Dorman, C.J. (1992) The DNA supercoiling-sensitive expression of the Salmonella typhimurium his operon requires the his attenuator and is modulated by anaerobiosis and by osmolarity. Mol. Microbiol. 6, 2467-2476.

Pruss, G.J., Manes, S.H. \& Drlica, K. (1982) Escherichia coli DNA topoisomerase I mutants: increased supercoiling is corrected by mutations near gyrase genes. Cell 31, 35-42.

Richardson, S.M.H., Higgins, C.F. \& Lilley, D.M.J. (1984) The genetic control of DNA supercoiling in Salmonella typhimurium. EMBO J. 3, 1745-1752.

Salazar, L., Fsihi, H., de Rossi, E., et al. (1996) Organization of the origins of replication of the chromosomes of Mycobacterium smegmatis, Mycobacterium leprae and Mycobacterium tuberculosis and isolation of a functional origin from $M$. smegmatis. Mol. Microbiol. 20, 283-293.

Sambrook, J., Fritsch, E.F. \& Maniatis, T. (1989). Molecular Cloning: a Laboratory Manual. Cold Spring Harbour, New York: Cold Spring Harbour Laboratory Press.

Sharp, P.A., Berk, A.J. \& Berget, S.M. (1980). Transcription maps of adenovirus. Meth. Enzymol. 65, 750-768.

Snapper, S.B., Melton, R.E., Mustafa, S., Kieser, T. \& Jacobs, W.R. Jr (1990) Isolation and characterization of efficient plasmid transformation mutants of Mycobacterium smegmatis. Mol. Microbiol. 4, 1911-1919.

Straney, R., Krah, R. \& Menzel, R. (1994) Mutations in the -10 TATAAT sequence of the $g y r A$ promoter affect both promoter strength and sensitivity to DNA supercoiling. J. Bacteriol. 176, 5999-6006.

Sugino, A. \& Bott, K.F. (1980) Bacillus subtilis deoxyribonucleic acid gyrase. J. Bacteriol. 141, 1331-1339.

Thiara, A.S. \& Cundliffe, E. (1993) Expression and analysis of two gyrB genes from the novobiocin producer, Streptomyces sphaeroides. Mol. Microbiol. 8, 495-506.

Urios, A., Herrera, G., Aleixandre, V. \& Blanco, M. (1990) Expression of the $\operatorname{rec} A$ gene in Escherichia coli topo I mutants. Mutat. Res. 243, 267-272.

Wang, J.C. (1985) DNA topoisomerases. Annu. Rev. Biochem. 54, 665-697.

Wang, J.C. (1996) DNA topoisomerases. Annu. Rev. Biochem. 65, 635-692.

Wu, Y. \& Dutta, P. (1995) Influence of DNA topology on expression of $t d s$ in Escherichia coli K12. Mol. Gen. Genet. 247, 764-767.

Zechiedrich, E.L., Khodursky, A.B. \& Cozzarelli, N.R. (1997) Topoisomerase IV, not gyrase, decatenates products of sitespecific recombination in Escherichia coli. Genes Dev. 11, $2580-2592$.

Received: 23 June 1999

Accepted: 21 September 1999 